\title{
PROCEEDINGS OF THE TWENTY-EIGHTH ANNUAL MEETING
}

\author{
BY MAURICE BROOKS, SECRETARY
}

The Twenty-eighth Annual Meeting of the Wilson Ornithological Club was held November 28-30, 1946, at Omaha, Nebraska, at the invitation of the Nebraska Ornithologists' Union. Business and social sessions were held in the Joslyn Memorial, and the Annual Dinner was given in the Hotel Fontenelle.

The Executive Council met on Thursday evening, November 28, at the Omaha Club. On Friday and Saturday there were two business sessions, three sessions devoted to the presentation of papers, and one session to the showing of color films of birds and other wildlife. A bird and mammal art exhibit, arranged by Walter J. Breckenridge, was held at the Joslyn Memorial. The artists whose works were shown had been members of the armed services of the United States during World War II and had had, therefore, opportunity to visit many parts of the world seldom reached by the zoologist. There was also an exhibit of Nebraska bird skins.

Following the Annual Dinner, the Nebraska Ornithologists' Union was host to members and guests of the Wilson Ornithological Club.

\section{Meeting of the Executive Council}

Present at the Executive Council meeting on Thursday evening were the following officers, members of the Council, and committee chairmen: George M. Sutton, Olin Sewall Pettingill, Jr., Maurice Brooks, Burt L. Monroe, Josselyn Van Tyne, Milton B. Trautman, George H. Lowery, Jr., Lawrence E. Hicks, George B. Thorp, Walter J. Breckenridge, R. Allyn Moser, and Harold F. Wing. President Sutton presided.

A summary of the Club's business and activities during the years 1942-45 was read and approved.

Reports were given by the Secretary, the Treasurer, and the Editor.

Josselyn Van Tyne was unanimously re-elected Editor for 1947.

It was voted that the Treasurer be responsible for maintaining the master membership list of the Club; that the Treasurer furnish the Editor with the corrected mailing list for each issue of The Wilson Bulletin; that the Treasurer furnish the Secretary with the official membership roll; and that membership application cards be printed with instructions for return to the Treasurer.

Affiliation with the Brooks Bird Club, of West Virginia, was approved.

Reports were received from the Affiliated Societies Committee, the Illustrations Committee, the Endowment Fund Committee, and the Library Committee.

An invitation to hold the 1947 Annual Meeting of the Club at Columbus, Ohio, was received from Edward S. Thomas, representing The Ohio State University, the Wheaton Club, and other organizations. It was voted to accept the invitation, and to hold the meeting on the week end following Thanksgiving.

The President announced the gift to the Club of five hundred dollars for the encouragement of research and the promotion of closer relations between the Club and the affiliated societies.

\section{Business Sessions}

The first business session was called to order by President George M. Sutton at 9:45 a.m. on November 29. The minutes of the 1941 meeting (published in The Wilson Bulletin for March 1942) were approved. The condensed minutes of 
meetings and actions of the Council for the years 1942-45 (during which no general meetings of the Club were held) were read and approved.

Reports of the Secretary, the Treasurer, and the Editor were read and approved.

The President appointed the following temporary committees: on Nominations, Lawrence H. Walkinshaw, Margaret M. Nice, S. Charles Kendeigh; on Auditing, Harold Wing and Bernard Baker; on Resolutions, Milton B. Trautman, F. W. Haecker, and Donald S. Farner.

The report of the Executive Council was read and approved.

Reports were received and approved from the Program Committee, the Endowment Fund Committee, the Affiliated Societies Committee, the Illustrations Committee, and the Committee on Local Arrangements.

The Secretary announced that the names of 172 proposed new members for 1946 were at the registration desk and that these names would be voted on at the final business session.

The final business session was called to order by President Sutton at 4:45 p.m. on November 30.

One hundred and seventy-two persons named by the Secretary and six additional persons named at the Annual Meeting were unanimously elected members.

The revised constitution for the Wilson Ornithological Club, published in The Wilson Bulletin for June 1946 was accepted.

Under the terms of the new constitution, President Sutton named the following persons to serve as Trustees for the Club: William G. Fargo, to serve for one year; R. Allyn Moser, to serve for two years; James H. Bruns, to serve for three years.

The report of the Auditing Committee was read and accepted.

The Resolutions Committee presented the following resolution, which was then adopted:

Resolved, that the Wilson Ornithological Club, at its Twenty-eighth Annual Meeting on November 28-30, 1946, in Omaha, Nebraska, wishes to express its sincere thanks to those who have made this meeting a memorable one; to the Omaha Society of Fine Arts for making available the facilities of the Joslyn Memorial, and to Eugene Kingman for arranging the art exhibit; to the members of the Nebraska Ornithologists' Union, and to Dr. R. Allyn Moser in particular; to the artists who contributed paintings, drawings, and photographs of birds exhibited during this meeting, and particularly to Dr. Walter J. Breckenridge for assembling this display; and to William Dilger, who contributed the drawing for the Annual Dinner menu.

Presentation and adoption of other resolutions followed.

The Nominating Committee proposed the following officers for the Club, who were then elected: President, George Miksch Sutton; First Vice-President, Olin Sewall Pettingill, Jr.; Second Vice-President, Maurice Brooks; Secretary, James B. Young; Treasurer, Burt L. Monroe; Elective Members of the Executive Council, Rudolf Bennitt, George H. Lowery, Jr., Milton B. Trautman.

The thanks of the Club were voted to William Ferguson for the use of his projector during the meetings.

The session adjourned at 5:05 p.m.

\section{Papers and Motion Pictures Sessions}

The opening session began on Friday morning, November 29, with an address of welcome by Dr. R. Allyn Moser, President of the Nebraska Ornithologists' Union, and a response by President George M. Sutton of the Wilson Ornithological Club. 
During the four sessions on Friday and Saturday a total of 22 papers and 8 motion picture films, all in color, were presented. The papers covered the following subjects: bird distribution (7); life history (4); wildlife management (2); conservation and education (3); bird behavior (1); bird photography (1) ; bird populations (1); techniques in studying bird migration (1); ornithological history (1) ; methods of publishing scientific information (1). The program of papers and films, together with brief abstracts, is given below.

\section{Opening Session, Friday Morning, November 29}

1. Wrison Tout, North Platte, Nebraska. Founders of the Nebraska Ornithologists' Union (10 minutes).

A paper of particular interest because the speaker is the only Charter Member of the Nebraska Ornithologists' Union still on the roll of that organization. The Union, now 47 years old, has just re-affiliated with the Wilson Ornithological Club.

2. Lawrence E. Hicks, Ohio State University. The 1945-46 Snowy Owl and Evening Grosbeak Invasion of the Ohio Area. Illustrated by slides (20 minutes).

A summary of data on Snowy Owls and Evening Grosbeaks that moved southward beyond their normal range into Ohio, the latter species in three separate waves.

3. Fred T. Hall, Ward's Natural Science Establishment, Rochester, New York. Observations on the Yellow-billed Tropic-bird. Illustrated by colored slides (20 minutes).

A report covering three years' observations of the nesting habits, feeding habits, and natural enemies of Phaëthon lepturus on the Bermuda Islands. Rats, which drove the birds away from certain otherwise favorable breeding areas, may, in the speaker's opinion, have extirpated also the local nesting populations of Bermuda Petrel (Pterodroma cahow) and Audubon's Shearwater (Puffinus lherminieri).

4. Burt L. Monroe, Anchorage, Kentucky. Observations of Water and Wading

Birds at the Falls of the Ohio. Illustrated by slides (20 minutes).

A summary of observations of waterfowl and shorebirds from 1930 to 1946, including comments on 87 species, 24 of which were new for the Kentucky State list. The study area extended from the western edge of the city of Louisville, in Jefferson County, to a point 14 miles upstream, in Oldham County. The speaker emphasized the need for confirmation of numerous early records.

5. F. W. Haecker, Kemmerer, Wyoming. Birds of La Barge Creek Basin, Lincoln and Sublette Counties, Wyoming (15 minutes).

A discussion of the climate, flora, and fauna of a 200 -square-mile montane tract (elevation 7,000 to 10,000 feet) in southwestern Wyoming, with emphasis on the birdlife, especially the Corvidae. The paper was based on observations made during 31 consecutive months (May 1944 to the fall of 1946). Especially notable were the speaker's comments on a feeding-counter maintained throughout the year at 8,000 feet elevation.

\section{FridAy AfTernoon}

6. Bert Harwell, National Audubon Society, New York. The Bonaventure Island Refuge. Colored motion pictures (30 minutes).

Among the photographs of the various seabirds which inhabit Bonaventure Island, Gaspé County, Quebec, were unusual shots showing Gannets plunging headlong into the water from considerable height. 
7. R. Allyn Moser, Omaha, Nebraska. Biotic Concept with It's Relation to Nebraska (20 minutes).

Discussion of the biotic provinces of Nebraska and of the birdlife characteristic of each province.

8. Mution B. Trautman, F. T. Stone Laboratory, The Ohio State University, Put-in-Bay, Ohio. Diurnal Movements of the Common Golden-eye about South Bass Island, Ohio, during the Autumn Migration. Illustrated by slides (15 minutes).

Golden-eyes observed about South Bass Island in November and December (until the freeze-up) appeared to roost about a mile offshore even in rough weather. About sunrise they flew directly toward the island, turned when 100 to 300 yards offshore, moved parallel to the shore, and alighted in small groups at reefs which they usually could see without difficulty because of the clearness of the water. Here they remained all day, feeding actively until noon, resting between noon and 4 p.m., and feeding again from 4 o'clock until sunset. At sunset they became restless. Presently one of them rose, and, followed by the others, flew out to the roost.

About 5 per cent of the water area was "reef," that is, Golden-eye feeding ground. The birds fed on crawfishes principally, but also on large aquatic insects, mollusks, and algae. Other species of ducks, notably Black Ducks, Red-breasted Mergansers, and Old-squaws at South Bass Island, and shoal-water ducks at baited ponds, quickly formed regular feeding habits, some of which involved restricted feeding areas.

9. NikolaAs Tinbergen, University of Leiden, Netherlands. The Study of Bird Behavior. Illustrated by slides (20 minutes).

A discussion of some of the stimuli employed by birds, fishes, insects, and other animals in eliciting certain responses. Illustrations showed color pattern and posture stimuli of the Stickleback, English Robin, etc.

10. Olin Sewall Petringinl, Jr., Carleton College, Northfield, Minnesota. Progress Report on the Whooping Crane Project (15 minutes).

During the spring and summer of 1946 Pettingill travelled widely in attempting to ascertain where the few surviving pairs of Whooping Cranes were breeding. On the Texas coast he saw a small number of wintering birds, among them adults feeding parti-colored young. In the Athabasca Lake district he flew over considerable areas of tundra vainly looking for the rare birds. The work was sponsored jointly by the National Audubon Society and the U. S. Fish and Wildlife Service.

11. John H. Baker, National Audubon Society, New York. The Program of the Audubon Society (15 minutes).

A discussion of the aims of the National Audubon Society, with emphasis on recently organized parts of the Society's work.

12. John Willard Baechle, St. Joseph's College. Bird Portraits. Illustrated by slides (20 minutes).

A series of close-up portraits of captive birds, with comments on the way in which the birds were held while being photographed.

13. Josselyn Van Tyne, University of Michigan. Methods of Publishing Scientific Information (10 minutes).

The organization and writing of scientific papers and notes, with remarks on titling, choice of the place of publication, and ways of safeguarding scientific accuracy through the whole editorial and publication process. 
14. David Damon, Nebraska Game, Forestation and Parks Commission, Lincoln, Nebraska. Seasonal Relationship of Bobwhite Quail to Woody Cover. Illustrated by slides (20 minutes).

A summary of data (based on flushing of over 150 coveys) pertaining to the dependence of the Bob-white on woodlots and osage orange hedges in southeastern Nebraska, particularly in winter. (Now published: Nebr. Bird Rev., 14, No. 2:3436.)

\section{Saturday Morning, November 30}

15. George J. Wallace, Michigan State College. Food Habits of Michigan Barn Owls (15 minutes).

An analysis of one year's pellets (805) and prey (2,266 vertebrate individuals) from a pair of Barn Owls and their two broods of young.

16. John H. Wampole, Nebraska Game, Forestation and Parks Commission, Lincoln, Nebraska. Hawk Populations in Nebraska (10 minutes).

In more than 40,000 miles of driving through central Nebraska in 1945 (all year) and 1946 (January 1 to September 1 ) the speaker obtained 2,257 sight records of 18 species of hawks - the rarest, the Duck Hawk (seen once); the commonest, the Sparrow Hawk (seen 800 times). He saw Sparrow Hawks and Marsh Hawks every month during the 20-month period. He saw two brown Marsh Hawks (adult females and immature birds) to one gray (adult male).

17. Wayne Short, National Audubon Society, New York. The Audubon Screen Tours Program. Illustrated by slides (20 minutes).

A brief history of the Audubon Screen Tours movement, with emphasis on the opportunities this program offers for conservation education.

18. Edson Fichter, University of Nebraska State Museum, Lincoln, Nebraska. Sight Record of Eastern Glossy Ibis in Nebraska (5 minutes).

Published under title, "Possible Sight Record of Eastern Glossy Ibis in Nebraska." Nebr. Bird Rev., 14, No. 2:44.

19-20. Jонn W. Scотт, University of Wyoming. Changing Environment and the Sage Grouse. A colored motion picture, The Sage Grouse. (30 minutes)

A report on the possible causes of the steady decrease in numbers of the Sage Grouse, once an abundant and important upland game bird in the western United States. In 1934 it was found in only 9 states. In the speaker's opinion changes in environment are largely responsible. These changes result principally from overgrazing (which has forced cattle into the sage-brush); topsoil erosion; drying up of the soil, seeps, water-holes and lakes. Young Sage Grouse depend on insect food obtainable in low-lying meadowlands. Where this moist habitat disappears, the Sage Grouse disappears too.

21. Adrian C. Fox, Soil Conservation Service, Lincoln, Nebraska. Soil and Water Conservation Education in Public Schools (15 minutes).

A discussion of the importance of soil and water to all forms of life and a plea for teaching conservation of these resources. 
22. Levi L. Mohler, Nebraska Game, Forestation and Parks Commission, Lincoln, Nebraska. Concerning Roost Flights of Prairie Chickens (15 minutes).

Having learned through repeated observation that all Prairie Chickens of a given flock ceased feeding and flew to their roost more or less simultaneously, Mohler simplified the problem of counting birds by flushing and counting one flock before the usual time for roost-flight, then driving to a place at which he could count a second flock flying to roost at the usual time.

23. George H. Lowery, Jr., Louisiana State University. The Use of the Telescope in Studies of Bird Migration. Illustrated by slides (30 minutes).

A plea for widespread collaboration in studying bird migration, using lowpower telescopes, with a discussion of the direction, frequency, and time of night at which birds have been seen flying across the face of the moon.

24. Seth H. Low, U.S. Fish and Wildlife Service, Jet, Oklahoma. Observations on Shorebirds, Jaegers, Gulls, and Terns on the Salt Plains National Wildlife Refuge, Alfalfa County, Oklahoma (20 minutes).

In the fall of 1941 a flood-control reservoir of 11,000 surface acres was created on the Salt Plains National Wildlife Refuge. About this artificial lake and the near-by salt plains, Low observed numerous charadriiform birds from 1941 to 1944, among them many species new for Oklahoma. The abundance of some species may indicate that a new line of flight has been established because of this feeding and resting place.

\section{SAturday Afternoon}

25. Edwin R. Kalmbach, Fish and Wildlife Service, Denver, Colorado. Birds, Beasts, and the Rainbow (45 minutes).

Presentation through colored motion pictures of experiments with colored grains, showing that Mourning Doves and other birds either failed to see or discriminated against green-colored grain, but that various mammals ate grain without apparent regard for its color.

26. William Ferguson, Omaha, Nebraska. This Curious World of Nature (30 minutes).

Colored motion pictures taken in Colorado of such montane birds as the Dipper, Williamson's Sapsucker, Mountain Bluebird, and Violet-green Swallow.

27. John H. Baker, National Audubon Society, New York. Southern Refuges of the Audubon Society (30 minutes).

Colored motion pictures of water birds on their Texas coast nesting grounds, with running comment on the relationships between bird colonies, economically important fish, and other elements of the biotic community.

28. Bernard Baker, Marne, Michigan. Mexican and West Indian Birds in Color. Presented by title.

29. Walter J. Breckenridge, Minnesota Museum of Natural History. Northward Migration of Sandhill Cranes in the Platte River Area of Western Nebraska (30 minutes).

Colored motion pictures of large flocks of Sandhill Cranes, most of which were feeding in stubble fields not far from farm buildings. Dancing of the birds seemed to be of a communal nature. 
30. Olin Sewall Petringill, Jr., Carleton College. Athabasca Sojourn (45 minutes).

Colored motion pictures taken during a summer reconnaisance of the supposed breeding ground of the Whooping Crane. Among the birds photographed were Horned Grebes, Long-billed Marsh Wrens, and Coots.

\section{The Annual Dinner}

The Annual Wilson Ornithological Club Dinner was held at the Hotel Fontenelle on Friday, November 29, with President George M. Sutton as Toastmaster. President Sutton introduced Dr. Nikolaas Tinbergen, of the University of Leiden, Mr. Wilson Tout, a founder of the Nebraska Ornithologists' Union, Mr. John H. Baker, Executive Director of the National Audubon Society, Dr. R. Allyn Moser, Chairman of the Committee on Local Arrangements, and Mr. and Mrs. F. L. Jaques.

The principal speaker was Mr. Roy N. Towl, engineer for the Omaha city parks system; his subject was "The Missouri River." Music was furnished by Mr. Arthur Randall, of Omaha.

Following the Annual Dinner, the Nebraska Ornithologists' Union was host to Wilson Ornithological Club members and guests at an informal reception in the Joslyn Memorial. Part of the time was spent viewing the exhibit of bird and mammal portraiture in the galleries of the Memorial.

\section{MINUTES OF THE WILSON ORNITHOLOGICAL CLUB, 1941-45}

Since the Wilson Ornithological Club has held no regular meeting since the Champaign-Urbana meeting, November 20-23, 1941, the Secretary has prepared the following summary of the Club's business and activities during the past five years.

The minutes and proceedings of the 1941 meeting were published in detail in The Wilson Bulletin for March 1942. To summarize them briefly: 1. The following officers were elected: President, George Miksch Sutton; First Vice-President, S. Charles Kendeigh; Second Vice-President, Olin Sewall Pettingill, Jr.; Secretary, Maurice Brooks; Treasurer, Gustav Swanson; Elective Members of the Executive Council, Burt L. Monroe, Eugene P. Odum, and Lawrence H. Walkinshaw. 2. Josselyn Van Tyne was re-elected Editor. 3. It was proposed to hold the 1942 meeting at Cornell University. 4. Affiliations with the Inland Bird Banding Association, the Virginia Society of Ornithology, and the Georgia Ornithological Society were approved. 5. Dues for Active Members were raised from $\$ 2.50$ to $\$ 3.00$, and for Associate Members from $\$ 1.50$ to $\$ 2.00$.

During the summer of 1942 it was decided that, because of wartime conditions, the proposed Ithaca meeting could not be held. President Sutton announced plans for an election of officers by mail ballot, the slate to be drawn up by a nominating committee and published in the Bulletin. The election resulted in the naming of the same officers for 1943 as had served during 1942, save that Milton B. Trautman was named as Treasurer to succeed Gustav Swanson, who had resigned. The Council re-elected Josselyn Van Tyne as Editor.

The March 1943 Bulletin carried full reports of the officers and committee chairmen, showing the Club to be active and in sound financial condition.

In the course of 1943 the Club's President, George M. Sutton, entered military service, the First Vice-President, S. Charles Kendeigh, serving the remainder of the year as Acting President; a meeting of the Club was again impossible, and another mail election of officers was held. The following officers were named: President, S. Charles Kendeigh; First Vice-President, Olin S. Pettingill, Jr.; Second Vice-President, Harrison F. Lewis; Secretary, Maurice Brooks; Treasurer, 
Milton B. Trautman; Elective Members of the Executive Council, Burt L. Monroe, Eugene P. Odum, and Lawrence H. Walkinshaw. By vote of the Council, Josselyn Van Tyne was re-elected Editor for 1944.

By the summer of 1944 a large amount of Club business had accumulated, some of which could not be carried on by mail. President Kendeigh called a meeting of the Executive Council at the Franz Theodore Stone Laboratory of Ohio State University, at Put-in-Bay, Ohio, August 11-12, 1944. Despite difficulties of travel, there was a good attendance of officers and committee chairmen. One important item of business was the re-incorporation of the Club; the Corporate Certificate was issued by the State of Illinois on October 16, 1944.

Officers for 1945 were again elected by mail ballot, the entire slate which served in 1944 being re-elected. Josselyn Van Tyne was re-elected Editor for 1945. A revision of the Club's constitution was outlined.

Travel conditions in 1945 did not permit a full meeting, but a meeting of the Executive Council and committee chairmen was held at Columbus, Ohio, on October 13, 1945. Work continued on a revision of the Constitution. It was announced that the Wisconsin Ornithological Society had expressed a desire to affiliate with the Wilson Ornithological Club, and favorable action on this matter was taken by the Council.

Another mail ballot was used to elect officers for 1946. The election resulted as follows: President, George Miksch Sutton; First Vice-President, Olin S. Pettingill, Jr.; Second Vice-President, Harrison F. Lewis; Secretary, Maurice Brooks; Treasurer, Burt L. Monroe; Elective Members of the Executive Council, Milton B. Trautman, Rudolf Bennitt, and George H. Lowery, Jr. Josselyn Van Tyne was re-elected Editor by the Council.

The five-year period covered by this report is noteworthy for the steady growth of the Club, and for the improvement of its financial position. Despite sharply rising costs, the increased membership of the Club and the fact that many members have raised the class of their membership have permitted our Treasurer to show a safe balance in the current fund each year.

Through the outstanding work of the Endowment Committee, the number of Life Members has shown a steady increase. This also contributes to our financial security.

\section{Respectfully submitted, Maurice Brooks, Secretary}

\section{REPORT OF THE SECRETARY, 1946}

The last full meeting of the Wilson Ornithological Club was held at Champaign-Urbana, Illinois, November 20-23, 1941, five years ago. At that time the effect of World War II was already being felt. We closed the year with 1,181 members, and it was freely predicted that in the event of protracted war, our membership would fall to seven or eight hundred. It is a tribute to the vitality of the Club that, despite the war and the necessary suspension of full meetings, the membership grew steadily during the entire five years. Much of the credit for this growth in membership is due to the two persons who served successively as chairman of the membership committee, Richard L. Weaver and Frederick M. Baumgartner. Credit is also due to many members of the Club who suggested new prospects, and who made special efforts to maintain, or to raise, the class of their own membership.

We now have 1,301 members on our rolls, the highest number which the Club has ever attained. During 1946 we have made a net gain of 101 members. At the close of 1945 our membership totalled 1,200, and during 1946 we lost, from all causes, 71 members, and gained 172 . 
Membership in the Club by classes (with the corresponding figures for 1945 in parentheses) is as follows: Founders, 2 (3) ; Life Members, 44 (34) ; Sustaining Members, 72 (67); Active Members, 449 (412); Associate Members, 734 (684). During 1946 the 172 new members were divided as follows: Sustaining Members, 3; Active Members, 44; Associate Members, 125.

From an ornithological society of somewhat local scope, our Club has grown to be an international organization. We now have members resident in every state in the Union, in most of the provinces of Canada, and in many foreign countries. Without attempting to give a complete summary we have at present members as follows:

$\begin{array}{lllrlr}\text { California } & 60 & \text { Maryland } & 21 & \text { North Dakota } & 10 \\ \text { Colorado } & 11 & \text { Massachusetts } & 43 & \text { Ohio } & 125 \\ \text { Connecticut } & 19 & \text { Michigan } & 92 & \text { Pennsylvania } & 63 \\ \text { Florida } & 17 & \text { Minnesota } & 45 & \text { Tennessee } & 20 \\ \text { Georgia } & 19 & \text { Missouri } & 25 & \text { Texas } & 25 \\ \text { Illinois } & 84 & \text { Montana } & 12 & \text { Virginia } & 18 \\ \text { Indiana } & 30 & \text { Nebraska } & 11 & \text { West Virginia } & 20 \\ \text { Iowa } & 32 & \text { New Hampshire } & 15 & \text { Wisconsin } & 50 \\ \text { Kansas } & 13 & \text { New Jersey } & 22 & \text { Canada } & 54 \\ \text { Kentucky } & 22 & \text { New York } & 114 & \text { Foreign } & 25\end{array}$

In the past year the Club has lost one of its Founders, Franklin Lorenzo Burns, of Berwyn, Pennsylvania. His death leaves but two living Founders, Dr. Lynds Jones and Dr. R. M. Strong.

Your Secretary, with this meeting, completes five years in the office. It has been a pleasure and an inspiration to work with the Club and its members. $\mathrm{He}$ bespeaks the same fine cooperation for his successor.

MAURICE BRooks, Secretary

The report of the Treasurer will be published in the June issue of the Bulletin.

The Wilson Bulletin Publication Dates

The actual dates of publication of the four numbers in 1946 were: May 21, August 2, October 2, December 21. 


\section{$2 \mathrm{BHL}$ Biodiversity Heritage Library}

Brooks, Maurice. 1947. "Proceedings of the Twenty-Eighth Annual Meeting." The Wilson bulletin 59(1), 59-67.

View This Item Online: https://www.biodiversitylibrary.org/item/215836

Permalink: https://www.biodiversitylibrary.org/partpdf/210693

\section{Holding Institution}

Harvard University, Museum of Comparative Zoology, Ernst Mayr Library

\section{Sponsored by}

IMLS LG-70-15-0138-15

\section{Copyright \& Reuse}

Copyright Status: In copyright. Digitized with the permission of the rights holder.

Rights Holder: Wilson Ornithological Society

License: http://creativecommons.org/licenses/by-nc-sa/4.0/

Rights: https://biodiversitylibrary.org/permissions

This document was created from content at the Biodiversity Heritage Library, the world's largest open access digital library for biodiversity literature and archives. Visit BHL at https://www.biodiversitylibrary.org. 